\title{
Protective Effect of Royal Jelly on Sperm Parameters, In-vitro Fertilizing Potential, and Oxidative Stress Indicators in the Testis of Mice Exposed to Ethephon
}

\author{
Ramin Jahangirfard ${ }^{1 *}$ \\ ${ }^{1}$ Dept of Anatomy and Embryology, Faculty of Veterinary Medicine, Urmia University, Urmia, Iran
}

\begin{tabular}{ll}
\hline Article Info & A B S T R A C T \\
\hline Article type: & Introduction: Ethephon is an organophosphorus that used to stimulate plant \\
Research article & growth. Royal Jelly is a substance with antioxidant properties and is effective for \\
& strengthening the immune system. This study aimed to determine the effect of \\
& Royal Jelly on sperm parameters, in vitro fertilization, and oxidative stress \\
indicators in mice.
\end{tabular}

Article History:

Received: 29 June 2020

Revised: 14 July 2020

Accepted: 08 November 2020

* Correspondence to:

Ramin Jahangirfard

Dept of Anatomy and

Embryology, Faculty of

Veterinary Medicine, Urmia

University, Urmia, Iran

Email:

r.jahangirfard@urmia.ac.ir
Material \& Methods: In this experimental study, 20 adult male mice (NMRI strain) were divided into four control and experimental groups. The experimental group received Ethephon at $480 \mathrm{mg} / \mathrm{kg}$. Royal Jelly was then administered orally and daily at a concentration of $200 \mathrm{mg} / \mathrm{kg}$ alone and in combination with Ethephon. After treatment, sperm samples were collected from the tail of epididymis to investigate sperm parameters and in vitro fertilizing potential; moreover, the testis tissue was taken for oxidative stress examination. A p-value less than 0.05 was considered statistically significant. (Ethic code: IR-UU_AEC-811/يد/3)

Findings: A decrease in the sperm motility and viability, fertilization rate, blastocyst, and hatching embryos, as well as an increase in DNA damage, lack of nuclear maturation, and blocked embryos was observed in the experimental groups, compared to the control group. Moreover, Total Antioxidant Capacity and Malondialdehyde in the groups receiving Ethephon decreased and increased, respectively. However, Royal Jelly can prevent the adverse effects of oxidative stress $(\mathrm{P}<0.05)$.

Discussion \& Conclusion: According to the results of this study, royal jelly can have an amelioration effect on epididymal sperm and in vitro fertilizing potential.

Keywords: Ethephon, In vitro fertilization, Oxidative stress, Royal jelly, Sperm parameters

$>$ How to cite this paper

Jahangirfard R. Protective Effect of Royal Jelly on Sperm Parameters, In-vitro Fertilizing Potential, and Oxidative Stress Indicators in the Testis of Mice Exposed to Ethephon. Journal of Ilam University of Medical Sciences. November 2021;29(4): 18-27. 


\title{
اثر محافظتى ذل رويال بر مؤلفههاى اسير مى، توان بارورى آزمايشكاهى و شاخصهاى استرس اكسيداتيو در بيضهُ موش سورى مواجهه شده با اتفون
}

\author{
(iD). \\ رامين جهانكيرفرد
}

ا كروه آناتومى و جنين شناسى مقايساى، دانشكدة داميز شكى، دانشكاه اروميه، اروميه، ايران

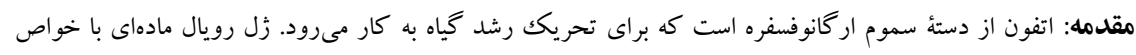
جكيده اطلاعات مقاله

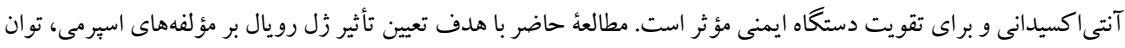

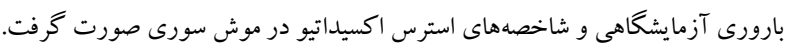

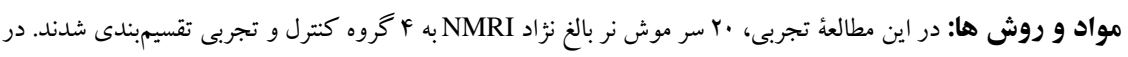

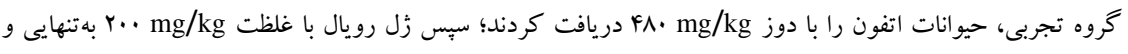

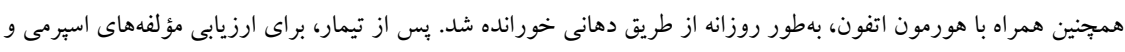

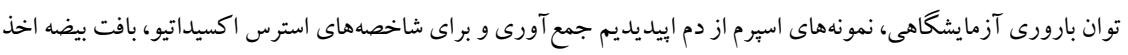

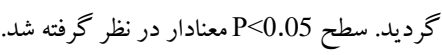

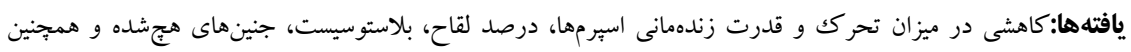

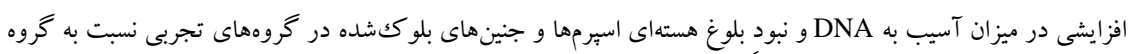

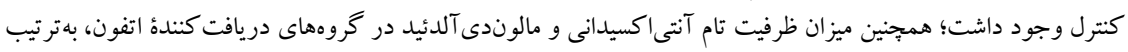

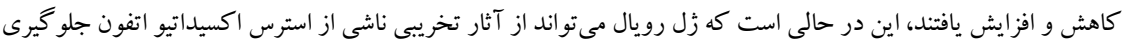
كند (P<0.05).

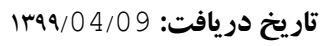
تاريخ داورى: تاريخ:

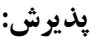
تاريخ $1399 / 08 / 18$

$$
\text { روامين جهانكيرفئول: }
$$

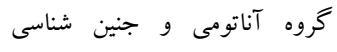

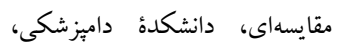
دانشخاه اروميه، اروميه، ايران انشكان دايز Email:

r.jahangirfard@urmia.ac.ir

بحث و نتيجه كيرى: بر اساس نتايج اين مطاله،، زل رويال مى بواند اثر بهبودى بر اسيرمهاى ابيديديمى و توان بارورى آزمايشكاهى داشته باشد.

وازههاى كليدى: زل رويال، اتفون، مؤلفهاى اسيرمى، استر اكسيداتيو، لقاح داخل آزمايشكاهى

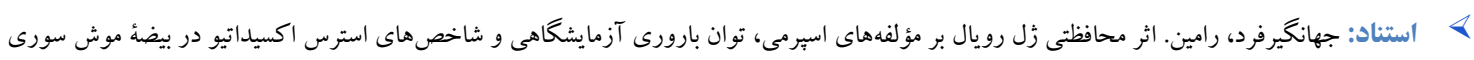

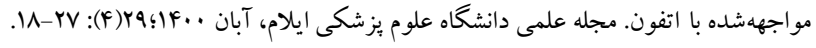


ايجاد كند كه به نظر مىرسد اين اثر ناشى از اين هورمون، به سبب اختلال در روند فيزيولوزيكك سلولى ازجمله سلولهاى مترشحه موجود در محور هييوفيزى- هييوتالاموسى باشد. كزارش شده است كه فعاليت بيولوزيكى آنتىاكسيدانى بهورمعمول در سلولهاى بدن وجود دارند (9). ايجاد استرس اكسيداتيو با بههم خوردن تعادل گُونهاى فعال اكسيرّن و آنتىاكسيدانها در ارتباط است كه درنهايت، به

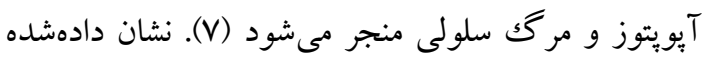

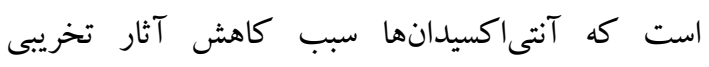
راديكالهاى آزاد روى دستخاه توليدمثل مى گردند (A). كزارش كردند كه اتفون سبب مشكلات فراوانى ازجمله نابارورى مردان از طريق القاى استرس اكسيداتيو مى

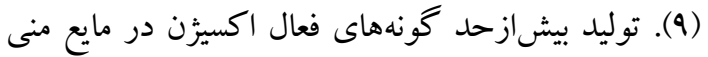
بهواسطة كلبولهاى سفيد، به همان اندازه كه توسط

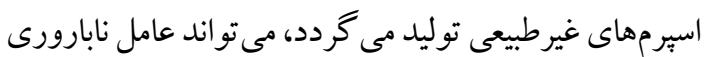
شود (·(). زل رويال ماده جسبناكى است كه بهوسيلة زنبورهاى عسل كارگر جوان توليد مى گردد (11). اين ماده خاصيت آنتى اكسيدانى دارد و همجنين بهعنوان ضدتومور، ضدباكترى و ضدديابت شناختهده است (YI). در ماده مؤثرءٔزل رويال موادى بنام استيل كولين وجود دارد كه سبب كاهش رسوب كلسترول خون در ديواره رگكها مى گردد (r|). بر اساس مطالعات بيشين، Silici و همكاران مشخص كردند كه ماده زل رويال بر آسيب استرس اكسيداتيو ايجادشده در بيضه، متعاقب مصرف سيس بِاتين،

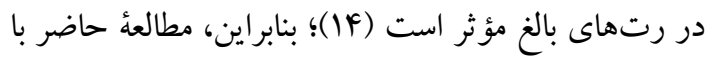
هدف بررسى آثار محافظتى زل رويال بر مؤلفههاى اسيرمى، توان بارورى آزمايشاهى و شاخصهاى استرس اكسيداتيو در موش سورى انجام يذيرفت.

\section{مواد و روش ها}

در اين مطالعه تجربى، تعداد ·r سر موش سورى نر بالغ نزاد NMRI آزمايش شد. حيوانات مطالعهده از مركز نكةدارى حيوانات آزمايشاهى دانشكدة داروسازى
امروزه، از مواد شيميايى مختلفى براى تسريع در روند رشد گياهان و ميوهها استفاده مىشود. ازجملة اين موارد مىتوان به كاز اتيلن، اتان، كلسيم كاربيد و اتفون اشاره كرد.

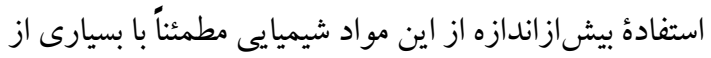
خطرات سلامتى همراه خواهد بود. سازمان حفاظت محيطزيست ايالاتمتحده در سال 1991 اظهار داشت كه فأه تنظيم كندههاى رشد گياه، در صورت لزوم، بايد در زمان و مقادير مناسب طبق دستورالعمل شركت سازنده استفاده

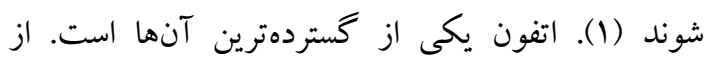

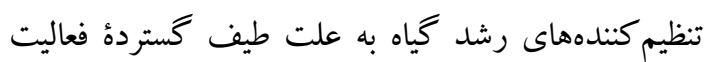
آنها استفادهشه است. اين هورمون بهعنوان محر كك رشد ئد كياهى كاربرد دارد و باعث تقويت گملدهى در گياهان

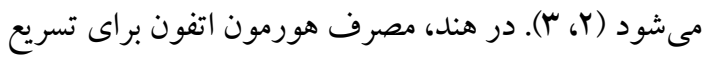
روند رشد موز پِ از برداشت محصول بسيار وسيع و

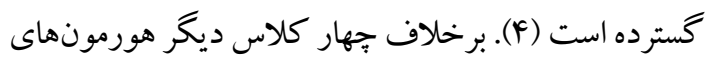

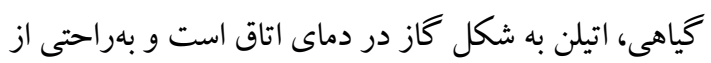

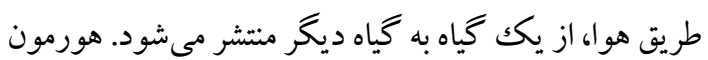
اتفون هنكامى كه بهصورت خوراكى در موشها تها تجويز

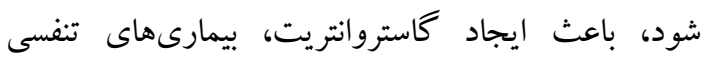

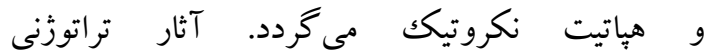
(ناقص الخلقهزايى) در رتها سبب جين خوردگى در شبكية جشم، ميكروفتالمى و رشد نكردن دم در حيوان شده است

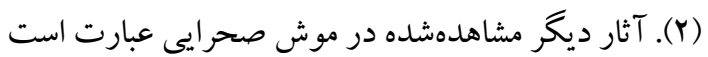
از: افزايش جشمخير در تومور سلولهاى جزاير لانخرهانس يانكراس (Y)، كاهش pH ادرار و وزن تيروئيد با افزايش كيستهاى مجراى تيرو گلوسال، افز ايش خارج رحمى غدو وند

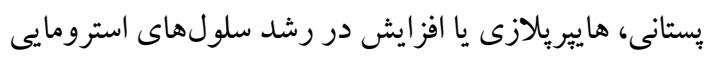
تخمدان، افزايش وزن كليهها، كلومرولواسكلروزيس، نفريت، افزايش هايبريلازى مجارى صفراوى،

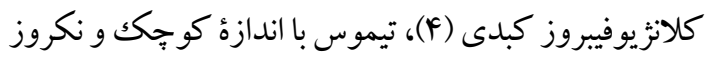
در معده (ه)، كلسيفيكاسيون مغزى، فيبروز قلب،

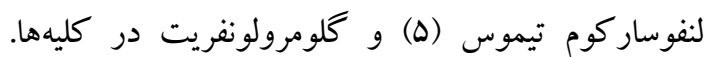
ثابتشده است كه هورمون اتفون مىتواند استرس اكسيداتيو 

اسپرمها، يكك قطره از اسِرم بر روى لام اضافه و سيس روى هر كدام از آنها يكك لامل قرار داده شد. در هر نمونه،

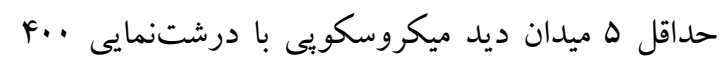
برابر بررسى گرديد و درنهايت، اسبرمهاى متحرك

بهصورت درصد بيان شدند (19).

ب. اسيرمهاى زنلدة: براى مشخص شدن درصد اسبرمهاى زنده، از رنگگ آميزى ائوزين - نيخروزين استفاده كرديد. مقدار •r ميكروليتر از اسيرم بر روى لام بهاضافهُ • † ميكروليتر از محلول رنكَى ائوزين تر كيب شد و بس از

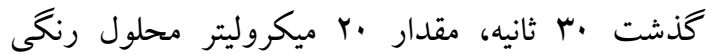
نيخروزين اضافه گرديد؛ سپس بِ از خشك شدن لامها، درصد اسيرمهاى زنده و مرده بهوسيلة ميكروسكوبِ نورى

$$
\text { بهصورت درصد گزارش شد (·r). }
$$

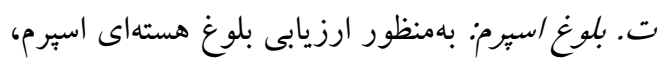

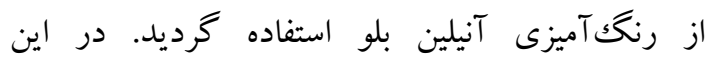
رنگك آميزى، اسيرمهاى نابالغ به علت هيستون فراوان به

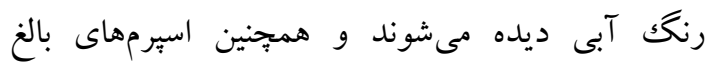
رنخ يذيرى كمترى دارند (Y) (Y). ث. آسيب به DNAسيرم: براى ارزيابى كيفيت اسپرم

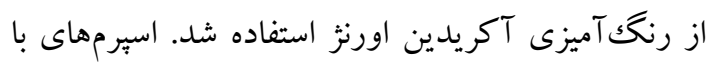

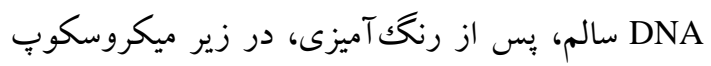

دانشگاه اروميه تهيه و در قفسهايى از جنس بروييلن به مدت ها روز نگهدارى گرديدند و آب و غذا بهطور آزاد، در اختيار حيوانات قرار داده شد. موشها به مدت يكك هفته با شرايط محيط ساز گار كثتند و سبس با شرايط استاندارد و رايج (Y Mاعت روشنايى و M ا ساعت تاريكى) نخهدارى شدند. در حين انجام مراحل كارى، همهُ يروتكل هاى اصول اخلاق در يثزوهش طبق دستورالعمل دانشكدة داميزشكى دانشگاه اروميه صورت گرفت. گروهها عبارت بودند از: گروه ا (كروه كنترل). حيوانات اين گرووه بهعنوان شاهد در نظر گرفتهشده و هيج مادهاى دريافت نكردند؛ گرووه r (گروه تجربى). در اين گروه، حيوانات اتفون را با دوز •YA ميلى گرم بر كيلو كرم از وزن بدن، روزانه بهصورت خوراكى دريافت كردند؛ گروه ب (كروه زل رويال). در اين كروه، حيوانات ماده زل رويال را با

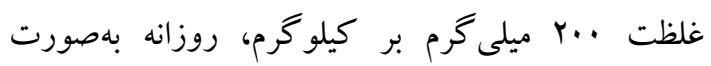
خوراكى دريافت كردند؛ گروه \& (كروه اتفون + زل

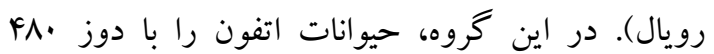
ميلى گرم بر كيلو گرم و همجنين زل رويال را با غلظت ميلى گرم بر كيلو گرم از وزن بدن، روزانه بهصورت خوراكى دريافت كردند. حيوانات مطالعهشده با استفاده از ترازوى ديجيتال توزين گرديدند و با تزريق داخل صفاقى

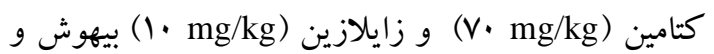
سبِ با استفاده از جابجايى مهرههاى گُردنى، آسان كشى شدند. يس از كنار زدن بوست و عضلات ناحئ شكمى، دم اييديديم با رعايت اصول استريل برداشته و بافتهاى همبند اطراف جدا گرديد؛ سيس دم اييديديم براى خروج اسبرمها به قطعات كوجٌك بريده شد. نمونههاى اخذشده در لوله فالكونهاى استريل حاوى يكك ميلىليتر محيط كشت HTF حاوى F ميلى گرم آلبومين سرم كاوى WV (BSA) درج، سانتى گراد، به مدت •و دقيقه قرار گرفتند تا اسِرمها آزاد و وارد محيط كشت شوند. درنهايت، سوسبانسيون حاوى اسِرم براى ارزيابى مؤلفههاى اسبرمى، با استفاده از

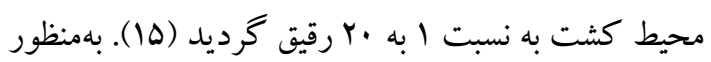


از تست تعقيبى توكى استفاده شد. سطح معنىدارى

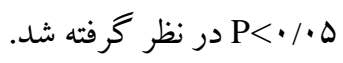

\section{يافته ها}

نتايج مربوط به مؤلفههاى اسبرمى؛ الف. ارزيابى تعداد

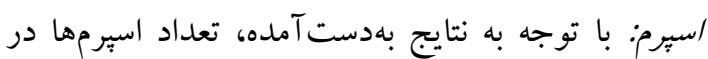

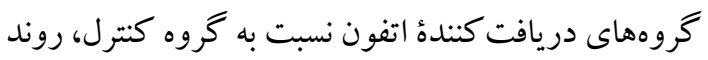

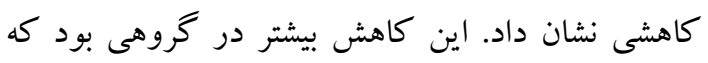

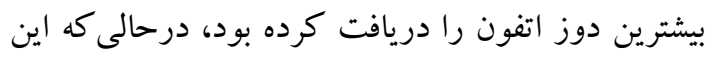
مؤلفه در گروه دريافت كنندة اتفون بهاضافهُ زل رويال

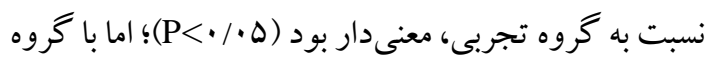
كنترل معنادار نبود. ب. ارزيابى درصد تحرك اسيرم: كاهشى در ميزان

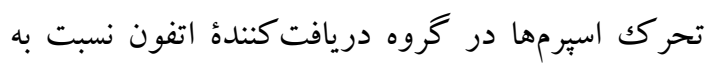

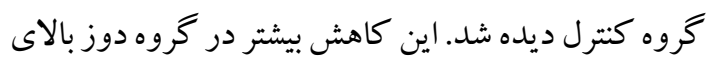

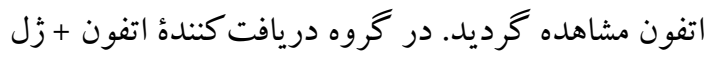
رويال در مقايسه با گروه تجربى، اختلاف معنادارى وجود درد درد

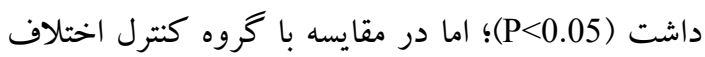
معنى دارى ديده نشد. ״. /رزيابى قابليت زنلدمانى /سيرم: نتايج بهدست آمده

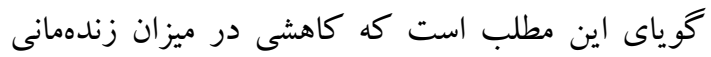
اسيرمها در گروههاى تجربى نسبت به گروه كنترل مشاهده كرديد. اين كاهش در گروه دريافت كنندة بيشترين دوز مصرفى اتفون در مقايسه با گروه كنترل معنادار بود

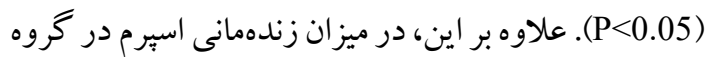
اتفون بهاضافه زل رويال در مقايسه با گروه كنترل، هيج

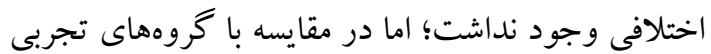
اين اختلاف معنادار بود. ت. ارزيابى بلوغ هستهاى /سيرم و درصد /سيرمهاى

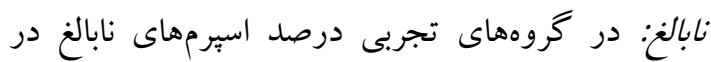

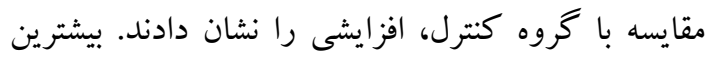
درصد اسبرمهاى نابالغ در گروهى مشاهده شد كه بيشترين دوز اتفون را دريافت كرده بود. اين مؤلفه در كروها دريافت كننده اتفون + زل رويال نسبت به گروه كرون كنترل
فلورسنت به رنغك سبز ديده مىشوند، درحالى كه اسبرمهاى با DNA آسيبديده به رنغك نارنجى تا قرمز

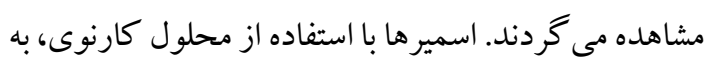

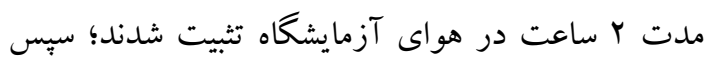

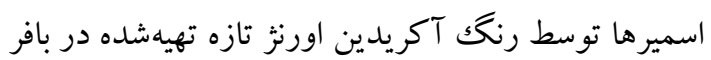
سيترات فسفات (19/. گرم يودر آكريدين اورنز در ... ميلىليتر بافر سيترات فسفات)، به مدت · ل دقيقه

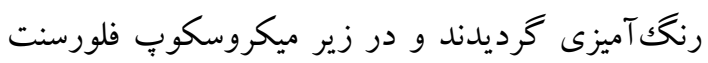

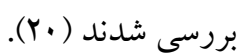

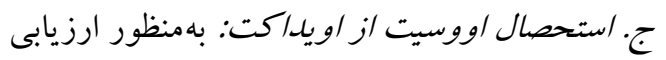

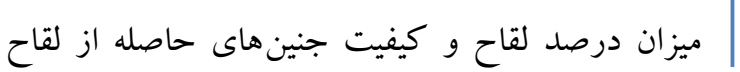

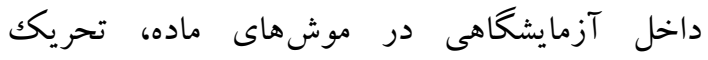
تخمكك گذارى صورت گرفت. بدين منظور، ابتدا

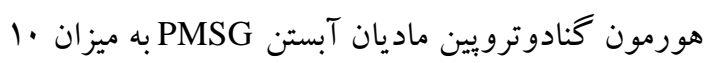

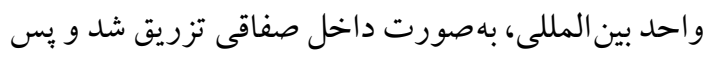

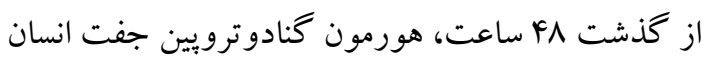

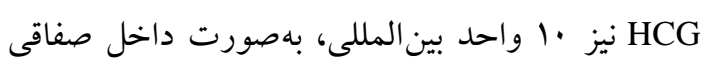

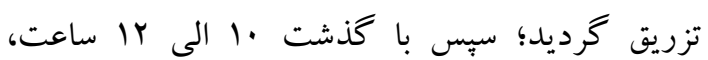
تخمككها از لولههاى اويداكت اخذ و در داخل محيط

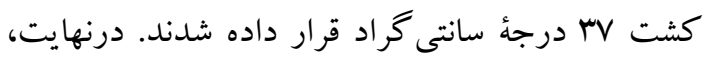

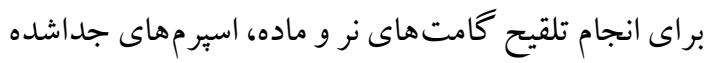

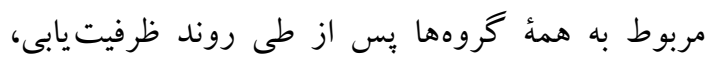

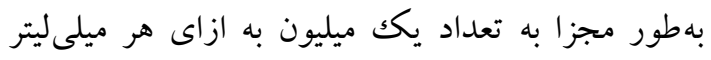
محيط كشت اضافه گرديد.

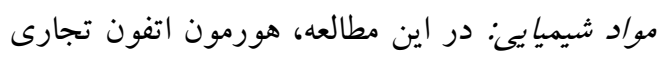

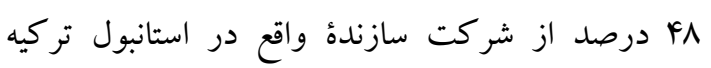
خريدارى شد؛ همجنين زل رويال زنبور عسل از مركز

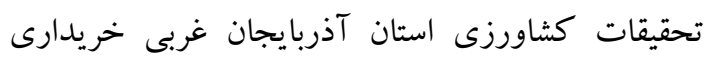

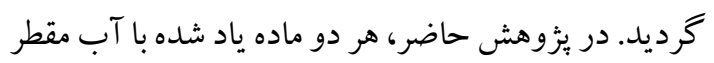
حل كشتند و از طريق دهانى خور انده شدند.

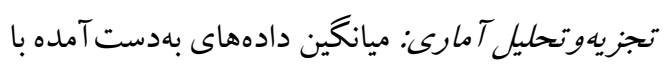
استفاده از نرمافزار SPSS vol.22 و به كاركيرى آزمون ميان

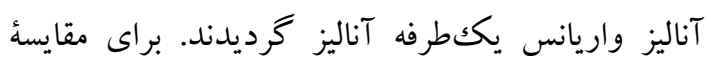

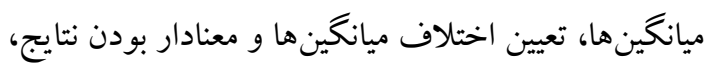


معنادار بود (P<0.05) (شكل شمارئ ). نتايج مربوط به توان بارورى آزمايشكاهى؛ الف.

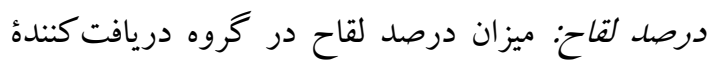

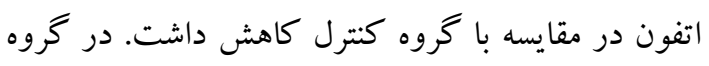

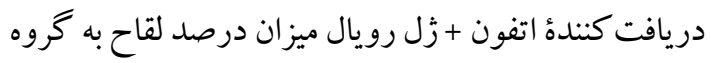
كنترل نزديكك شد و هيج اختلاف معنادارى با يكديخر نداشتن (شكل شمارة r و جدول شمارة ()).

\section{a}

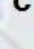

\section{DS}

c

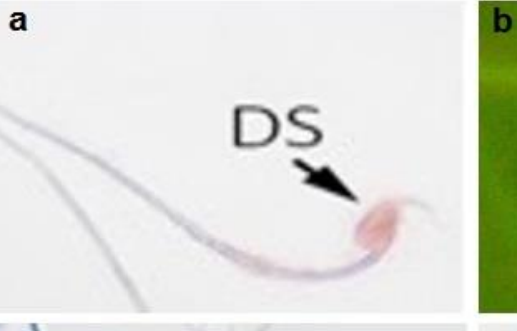

d
معنادار نبود؛ اما در مقايسه با گروه دريافت كنندة اتفون معنادار بود (P<0.05) (شكل شمارة () ). ث. درصد اسيرمهاى با DNA آسيبديلدة: افزايش

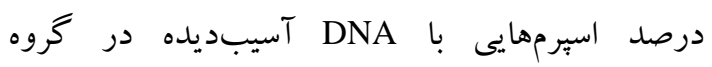
دريافت كننده اتفون نسبت به گرووهاى كنترل مشاهده

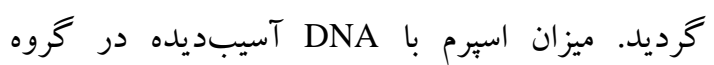

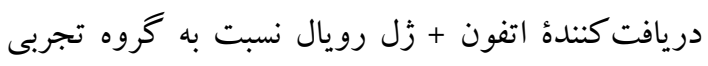

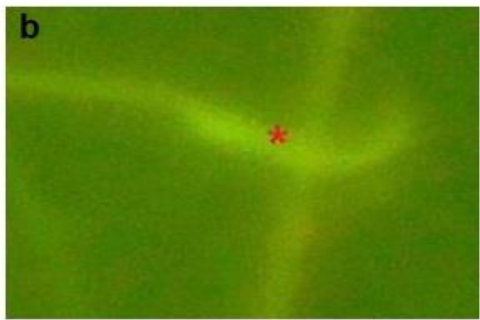

15

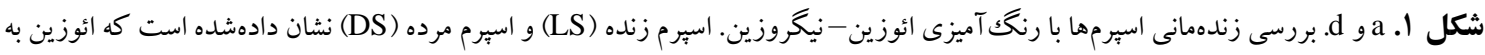

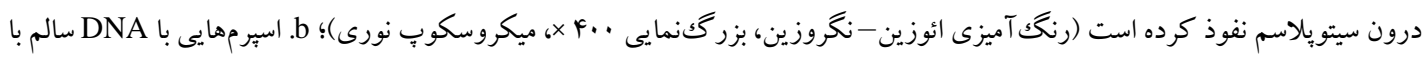

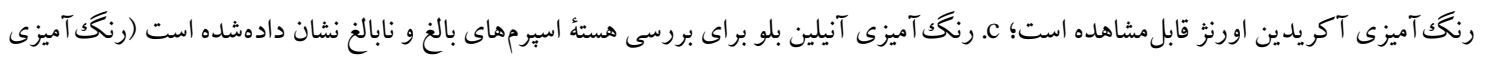

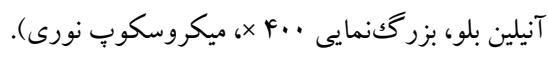

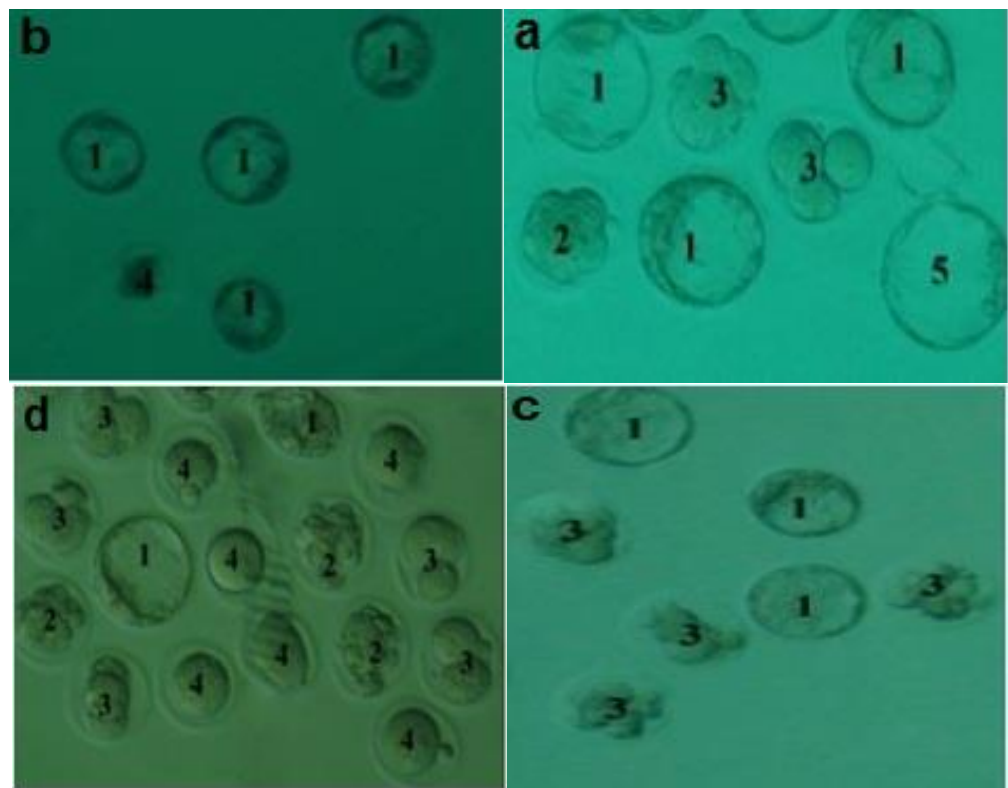

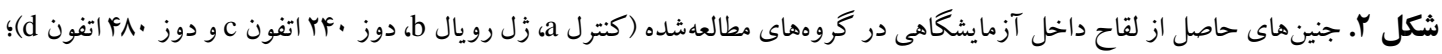

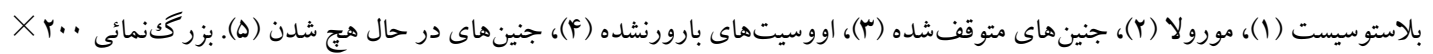




\begin{tabular}{|c|c|c|c|c|}
\hline كروه ع (ظل رويال) & كروه ץ (اتفون + ذل رويال) & كروه r (دوز · · & كروه ا (كنترل) & \\
\hline$\Lambda \Delta / 94 \pm 1 / 99^{\mathrm{a}}$ & $M / r F \pm 1 / / r^{\mathrm{a}}$ & $F \wedge / 99 \pm r / 1 Q^{c}$ & $q \cdot / V \Lambda \pm 1 / q \mu^{\mathrm{a}}$ & درصد لقاح \\
\hline$F \Psi / \Delta ৭ \pm \Delta / r \Delta^{\mathrm{a}}$ & $F r / \Delta r \pm 9 / \Delta r^{a}$ & $r \Delta / 1 \Delta \pm F / V q^{c}$ & $r \Lambda / \Lambda q \pm r / \mu r^{a}$ & درصد بلاستوسيست \\
\hline$r \cdot / \Delta r \pm r / q r^{a}$ & $19 / r r \pm \Delta / \cdots^{a}$ & $\cdot \pm$ & $r Y / G Y \pm Y / A \cdot a$ & جنينهاى هج شده \\
\hline$\kappa r / \Delta q \pm Y / V F^{a}$ & $F F / F V \pm Y / Y D^{a}$ & $\Delta F / q q \pm \Delta / \Delta q^{c}$ & $F F / V Q \pm Y / \Lambda q^{a}$ & جنين هاى بلو ككشده \\
\hline
\end{tabular}

"حروف متفاوت بيانكر وجود اختلاف معنادار ميان گروههاى مطالعه شده است.

جنينهاى بلوككشده در گرووه دريافت كننده اتفون در مقايسه با كروه كنترل ديده شد. درصد جنينهاى بلو ككشده در گروه دريافت كنندهُ اتفون +زّل رويال از نظر آمارى به گروه كنترل نزديك گرديد و هيج اختلاف معنادارى ميان آنها مشاهده نشد (شكل شماره ب و جدول

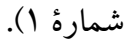
نتايج مربوط به فاكتورهاى /سترس اكسيد/تيو؛ الف. ظرفيت تام آنتى كسيد/نى (TAC): نتايج بهدست آمده نشان داد كه ميزان ظرفيت تام آنتىاكسيدانى در كروه دريافت كنندهُ اتفون نسبت به كروه كنترل كاهش داشت. هيج اختلاف معنادارى ميان كروههاى دريافت كننده اتفون + زل رويال در مقايسه با گروه كنترل مشاهده نگگرديد. اين در حالى است كه اختلاف معنىدارى ميان گروه اتفون + زل رويال نسبت به كروههاى تجربى ديده شد (P>0.05)

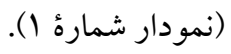

ب. درصد بلاستوسيست: نتايج نشان داد كه درصد بلاستوسيست در كروه دريافت كننده اتفون نسبت به كروه كنترل، كاهش يافته است. افزايش در ميزان درصد بلاستوسيست در كروهى ديده شد كه اتفون را همراه با زل رويال دريافت كرده بود؛ بنابراين، زل رويال توانست آثار تخريبى راديكالهاى آزاد سمى توليدشده بهوسيلة اتفون را تا حدودى جبران كند (شكل شمارهُ بو جدول

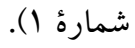
ب. درصل جنينهاى هج شلده: كاهش در ميزان جنينهاى حاصل از لقاح آزمايشگاهى در كروه دريافت كننده اتفون نسبت به كروه كنترل مشاهده شد، درحالى كه در گروه دريافت كننده اتفون + زل رويال ميزان جنينهاى هجشده به كروه كنترل نزديكك كرديد (شكل شمارة r و جدول شماره (1). ت. درصل جنينهاى بلوككشله: افزايشى در ميزان

\section{TAC}

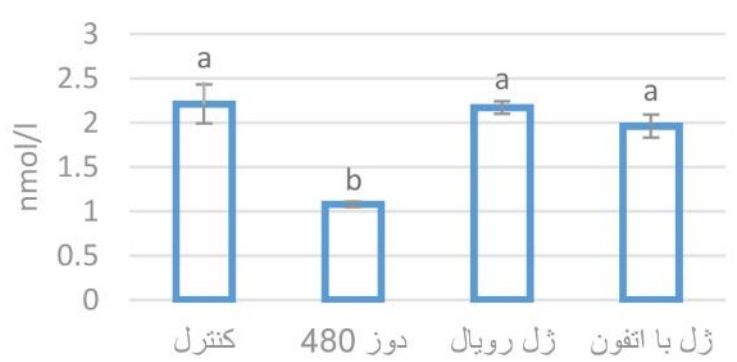

نوز انفون

\section{MDA}

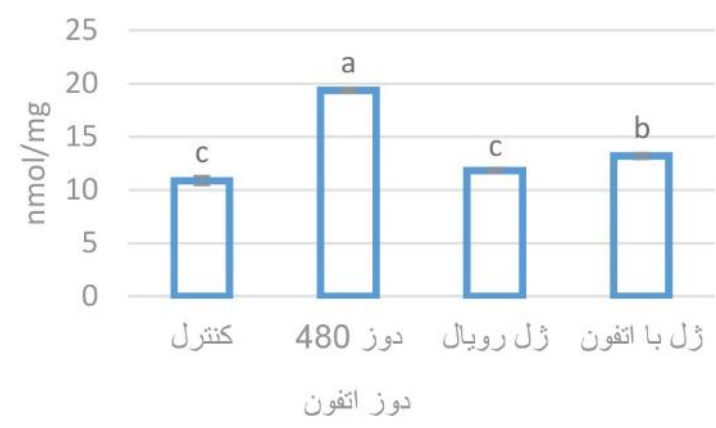

نمودار ا. مقايسٔ ميانگين ظرفيت تام آنتى اكسيدانى و مالوندى آلدئيد نشان دادهشده است.

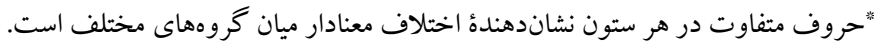


(YO). نتايج مطالعهُ حاضر با مطالعات مشابه همخرا است.

$\overline{7}$

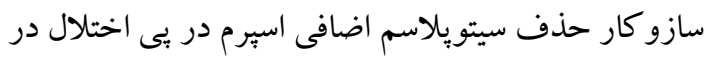
دجار نقص مىشود كه در اين حالت، اسيرمها سيتويلاسم اضافى دارند و از نظر مورفولوزى نابالغ هستند (Y) هون.

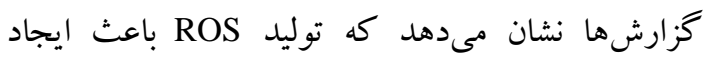

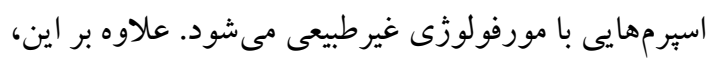

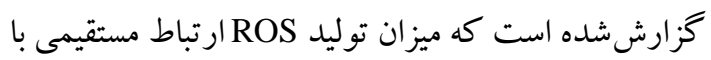
ميزان توليد اسبرمهاى غيرطبيعى و نابالغ دارد (Y) (ب)؛

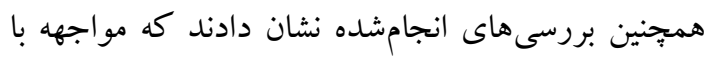
اتفون در دوزهاى بالا، روى سلولهاى سرتولى و ليديگك آندان سلولهاى سرتولى و به دنبال آن، اختلال در اسبرميوزنز

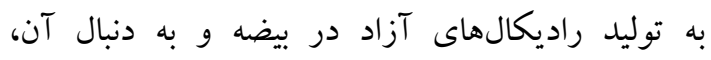

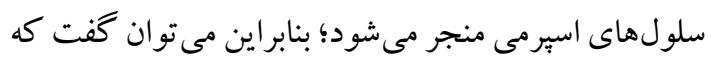
كاهش عملكرد سلولهاى ليديخك در بافت بيناينى بيضه سبب كاهش در ميزان ترشح هورمون تستوسترون نيز

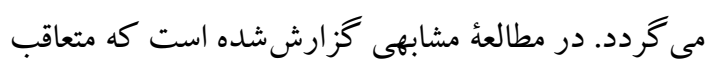
مصرف اتفون، كاهشى در ميزان شمارش تعداد اسبرم، درصد تحرك و قابليت زندهمانى اسبرم ديده شده، درحالى كه درصد ناهنجارىهاى اسبرمى افزايشى را نشان داده است (YV). نتايج تحقيق حاضر با مطالعات بيشين همخوانى دارد. بهطور كلى بيانشده است كه استفاده از

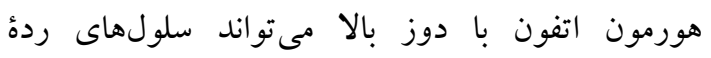

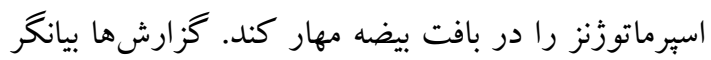

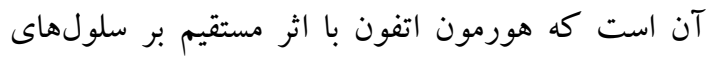

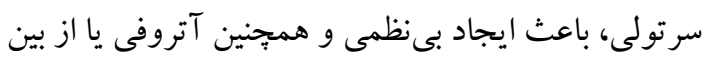

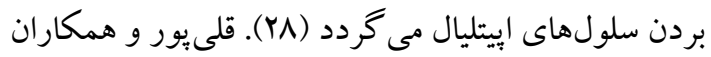
در سال \& ا ب Fز ارش كردند كه استفاده از زل رويال سبب

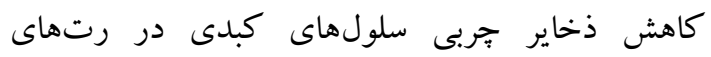
يلى كيستيك شده است و آثار تخريبى ناشى از استرس

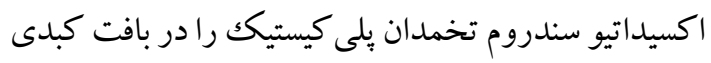

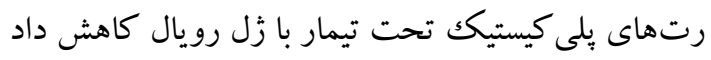

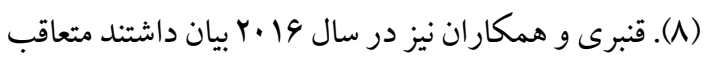
القاى ديابت تجربى در رتها و به دنبال آن، استفاده از زل فئل

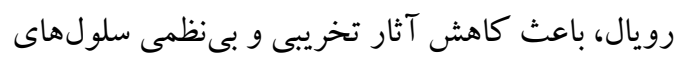

ب. مالوندىى آلدئيد (MDA): نتايج بهدست آمده نشان داد كه ميزان مالوندى آلدئيد در گروه دريافت كنندة اتفون

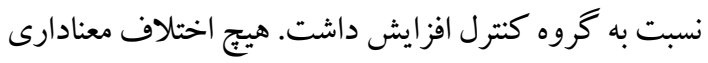

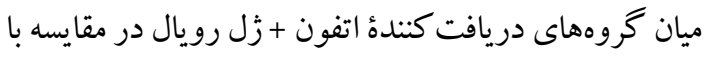

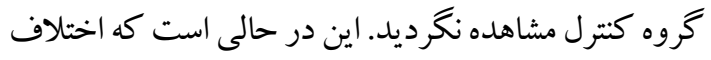

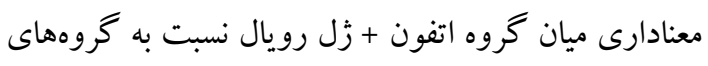
تجربى ديده شد (P<0.05) (نمودار شمارهُ ()).

\section{بحث و نتيجه كيرى}

در اين مطالعه مشاهده شد كن كه درى گروههاى دريافتكنندة اتفون، درصد DNA صدمهديده، درصد اسيرمهاى با هستهٔ نابالغ، MDA و درصد درصد جنينهاى بلو كسشده بهطور جشمخيرى افز ايش ييدا كرده بود. علاوه

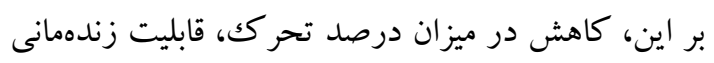

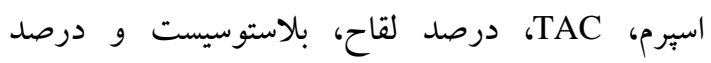
جنين هاى هجشده وجود داشت. در اين يزوهش، استفاده

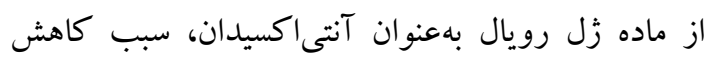
آسيبهاى ناشى از اتفون شد. محققان نشان دادند كه رونه

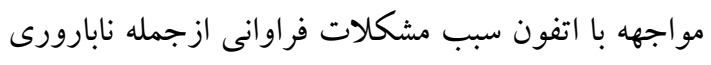

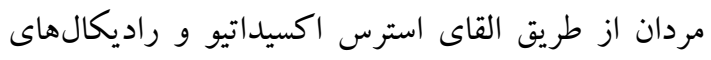

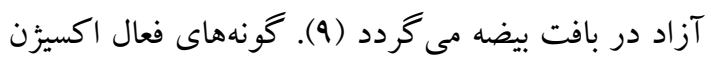

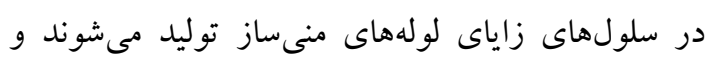

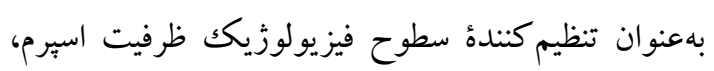
واكنش آكروزومى و اتصال اسبرموسيت عمل مي كنند

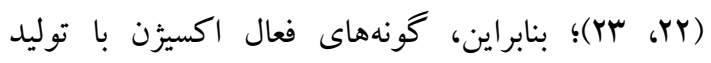
راديكالهاى آزاد باعث اختلال در فعاليت سلولهاى

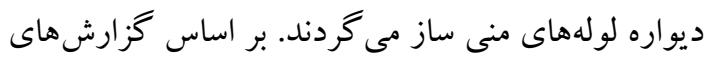

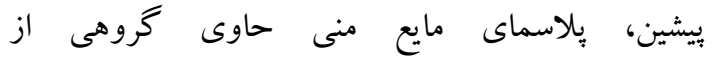

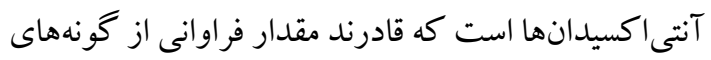

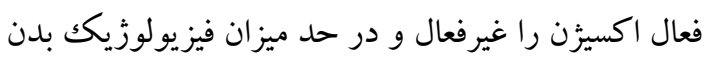
حفظ كنند (YF). استرس اكسيداتيو در اسبرم سبب ايجاد

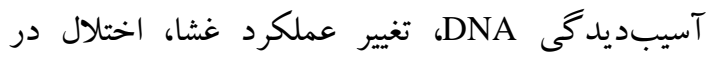

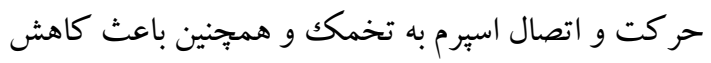

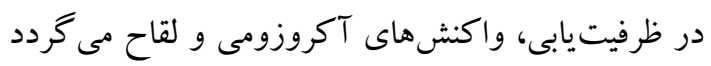




$$
\begin{aligned}
& \text { زل رويال با داشتن تر كيبات غنى از فعاليتهاى بيولوزيكى، } \\
& \text { عامل مؤثر در برابر آسيبهاى اكسيداتيو است و مصرف } \\
& \text { خوراكى آن بهصورت روزانه مىتواند آثار تخريبى ناشى } \\
& \text { از هورمون اتفون را بهطور جشمخيرى كاهش دهد. }
\end{aligned}
$$$$
\text { تشكر و قدردانى }
$$

هزينه انجام اين ئزوهش توسط دانشجوى دكتراى

تخصصى رشته داميزشكى كرايش آناتومى و جنين شناسى

مقايسه اى دانشگاه سراسرى اروميه با كد اخلاق در

يثزوهش س//بد / 1 1 تأمين شده است. بدينوسيله از تمام افراد

شر كت كننده در يزوهش حاضر، تقدير و تشكر مى گردد.

$$
\text { تعارض منافع }
$$

نويسند كان اعلام مى كنند كه تضاد منافعى در اين

مطالعه وجود ندارد.

كد اخلاق: 3/ يد/IR-UU_AEC-811

\section{References}

1. Yavuzkocaman A, Kılıc E. Evaluation of the genotoxicity of commercial formulations of ethephon and ethephon cyclanilide on Allium cepa L. root meristematic cells. Caryologia 2017; 70: 229-37-doi.10.1080/00087114.2017.1329960.

2. Rodwell DE, Spencer AG, Allen S. Teratology study in rats. Prep Int Res Dev Corp1980;3: 264-7. doi.10.1016/0041-008X (74)90107-0.

3. Ferrell J. 104-week chronic administration of ethrel in male and female rats. Final Pathol Rep Proj2013;747: 141-263. doi.10.4103/23194170.155589.

4. Vanmiller J. Lifetime dietary combined chronic toxicity and oncogenicity study with ethephon in albino Rats. Bushy Run Res Cen Rhone Poulenc 1989; 2:24-7. doi.10.4103/2319-4170.155589.

5. Klonne D. Supplemental historical control data requested for the lifetime dietary oncogenicity study with ethephon in albino Mice. Bushy Run Res Cent Rhone Poulenc ;1994;3: 17.

6. Victor VM, Rocha M, Iafuente M. Immune cell free radicals and antioxidants in sepsis. Int Immuno Pharmacol 2004; 4:327-47. doi.10.1016/j.intimp.2004.01.020.

7. Gholipour Z, Nejati V, Najafi G, Karimpour Z, Khaneshi F.] The protective effect of royal jelly on liver tissue of adult female rats with experimental polycystic ovarian syndrome] . Qom Uni Med Sci J 2014; 8:35-41. (Persian)

$$
\begin{aligned}
& \text { ردهُ اسيرماتوزْنز در بافت بيضه مىشود (Yq)؛ بنابراين } \\
& \text { كفته مى شود مادهُ زل رويال بهعنوان آنتى اكسيدانى نيرومند } \\
& \text { و ضدديابت تلقى مى گردد. نتايج مطالعات شاليزار جلالى ملى } \\
& \text { و همكاران نشان مىدهد كه مصرف داروى استانوزولول } \\
& \text { باعث ايجاد آثار نامطلوب بر روى شمارش تعداد اسبرم، } \\
& \text { تحرك و آسيب به DNA اسيرم مى شود. به دنبال آن } \\
& \text { مشاهده كردند كه استفاده از زل رويال سبب آثار مطلوب } \\
& \text { و بهبود مؤلفههاى اسيرمى مى گردد (·r). ترميم و بهبود } \\
& \text { آثار نامطلوب اتفون احتمالاً به علت وجود خاصيت } \\
& \text { آنتى اكسيدانى نيرومند و ضد راديكالهاى آزاد زل رويال } \\
& \text { در بدن باشد. نتايج بهدست آمده در اين تحقيق با مطالعات } \\
& \text { ييشين مطابقت دارد. نتايج نشان داد كه ميزان ظرفيت تام } \\
& \text { آنتىاكسيدانى و مالوندى آلدئيد متعاقب مصرف زل } \\
& \text { رويال، تا حدودى به گروه كنترل نزديككتر شد؛ بنابراين، } \\
& \text { با توجه به نتايج مطالعهُ حاضر، آثار محافظتى زل رويال بر } \\
& \text { مؤلفههاى اسبرمى، توان بارورى آزمايشگاهى و و } \\
& \text { شاخصه هاى سيستم استرس اكسيداتيو بهوضوح مشخص } \\
& \text { كرديد. از يافتههاى اين مطالعه مىتوان نتيجه گيرى كرد كه }
\end{aligned}
$$

8. Lee JY, Baw CK, Gupta S, Aziz N, Agarwal A. Role of oxidative stress in polycystic ovary syndrome. Curr Wome Health Rev 2010:96-107. doi.10.2174/157340410791321336.

9. Dutta U. Evaluation of ethephon induced oxidative stress to gonadal disorder and its amelioration by ethanolic extract of shoot of Bambusa balcooa roxb. in albino Rat. Toxicol Lett 2015; 4:63. doi.10.1016\%2Fj.toxlet.2015.08.776.

10. Sharma RK, Agarwal A. Role of reactive oxygen species in male infertility. Urology 1996; 48: 83550. doi.10.1016/S0090-4295(96)00313-5.

11. Narita Y, Ohta S, Suzuki KM, Nemoto T, Abe K, Mishima S. Effects of long term administration of royal jelly on pituitary weight and gene expression in middle aged female rats. Biosci Biotech Biochem 2009; 73:431-3. doi.10.1271/bbb.80556.

12. Abdelwahhab MA, Hassan AM, Amer HA, Naguib KM. Prevention of fumonisin induced maternal and developmental toxicity in Rats by certain plant extracts. J Appl Toxicol 2004; 24:469-74. doi.10.1002/jat.1000.

13. Wei W, Wei M, Kang XJ, Deng HH, Lu ZH. A novel method developed for acetylcholine detection in royal jelly by using capillary electrophoresis coupled with electrogenerated chemiluminescence based on a simple reaction. Electrophoresis 2009; 30:1949-52. doi.10.1002/elps.200800721.

14. Silici S, Ekmekcioglu O, Eraslan G, Demirtas A. 
Antioxidative effect of royal jelly in Cisplatininduced testes damage. Urology 2009; 74:545-51. doi.10.1016/j.urology.2009.05.024.

15. Anand $\mathrm{P}$, Thomas SG, Kunnumakkara AB, Sundaram C, Harikumar KB, Sung B. Biological activities of curcumin and its analogues made by man and mother. Biochem Pharmacol 2008; 76: 1590611. doi.10.1016/j.bcp.2008.08.008.

16. Jahangirfard R, Najafi G, Shalizar Jalali A, Ahmadi A. [The effect of ethephon investigation on sperm parameters and in vitro fertilizing potential in adult male Mice] . J Fasa Uni Med Sci 2020; 10: 2545-57. (Persian)

17. Malekian R, Abdanipour A, Sohrabi D. Antioxidant and neuroprotective effects of lycopene and insulin in the hippocampus of streptozotocin induced diabetic Rats. Biomed Rep 2019; 10: 47-54. https://doi.org/10.3892/br.2018.1171.

18. Zambrano E, Rodriguez-Gonzalez GL, Guzman C, Garcia-Becerra R, Boeck L, Menjivar M, Larrea F, Nathanielsz PW. A maternal low Protein diet during Pregnancy and lactation in the Rat impairs male reproductive development. J Physiol 2005; 563: 275-84. doi.10.1113/jphysiol.2004.078543.

19. Mohamadghasemi F, Faghani M, Fallahkarkan M. The protective effect of melatonin on sperm parameters, Epididymis and Seminal vesicle morphology in Adult mouse treated with Busulfan. J Iran Anat Sci 2010; 10: 25-36.

20. Menkveld R, Wong WY, Lombard CJ, Wetzels AM, Thomas CM, Merkus HM, et al. Semen parameters including WHO and strict criteria morphology in a fertile and subfertile population: an effort towards standardization of invivo thresholds. Hum Rep 2001; 16: 1165-71. doi.10.1093/humrep/16.6.1165.

21. Nasr-Esfahani MH, Razavi S, Mardani M. Relation between different human sperm nuclear maturity tests and in vitro fertilization. J Assist Rep
Gen2001; 18: 221-7.

22. Agarwal A, Saleh RA. Role of oxidants in male infertility rationale significance and treatment. Urol Clin North Am2002; 29: 817-27. doi.10.1016/S0094-0143(02)00081-2.

23. Agarwal A, Saleh RA, Bedaiwy MA. Role of reactive oxygen species in the pathophysiology of human reproduction. Fert Ster 2003; 79: 829-43. doi.10.1016/S0015-0282(02)04948-8.

24. Agarwal A, Sekhon LH. The role of antioxidant therapy in the treatment of male infertility. Hum Fert2010; 13: 217-25. doi.10.3109/14647273.2010.532279.

25. Varnet P, Fulton N, Wallace C, Aitken RJ. Analysis of a plasma membrane redox system in rat epididymal spermatozoa. Biol Reprod. 2001; 65: 13-1102. doi.10.1095/biolreprod65.4.1102.

26. Venkatesh S, Gurdeep Singh M, Prasad Gupta N, Kumar R, Deecaraman M, Dada R. Correlation of sperm morphology and oxidative stress in infertile men. Int J Rep Biomed 2009; 7: 29-34.

27. Abdeldaim MA, Tousson E, Elsayed IET, Awd WM. Ameliorative effects of saussurea lappa root aqueous extract against ethephon induced reproductive toxicity in male Rats. Environ Toxicol 2018;3: 1-10. doi.10.1002/tox.22669.

28. Attia SM. Dominant lethal mutations of topoisomerase II inhibitors etoposide and merbarone in male Mice a mechanistic study. Arch Toxicol2012; 86: 725-31.

29. Ghanbari E, Nejati V, Khazaei M. Antioxidant and protective effects of Royal jelly on histopathological changes in testis of diabetic rats. Int J Rep Biomed 2016; 14:519.

30. Jalali AS, Najafi G, Hosseinchi M, Sedighnia A. Royal Jelly alleviates sperm toxicity and improves in vitro fertilization outcome in stanozolol treated mice. Iranian J Rep Med2015; 13:15. 